\title{
8A14 マイコン制御による片手・片足で操作できる車いすの実用化
}

Practical development of single side driven wheelchairs by microcomputer control

\author{
○谷 正 史（金沢工大） 正 鈴木亮一（金沢工大） 小林伸明（金沢工大） \\ Masashi TANI, \\ Ryoichi SUZUKI, \\ Nobuaki KOBAYASHI,
}

Kanazawa Institute of Technology

7-1 Ohgigaoka, Nonoichi, ISHIKAWA 921-8501

Key words: Human-machine control, Single side wheelchair, Standard wheelchair, Microcomputer control, Internal model control, LQ control

\section{1.はじめに}

脳出血や脳血栓などの脳血管障害や脳外傷、脳腫瘍な どにより、片麻痺になった方を対象とした車いすに、片 手駆動式の車いすがある。この車いすにはダブルハンド リム式とレバー式があるが、ダブルハンドリム式は操作 が困難、レバー式は旋回半径が大きいなどの問題点があ る。これらのことから、実際に多くの人が標準型車いす を用いて、健側（麻㾝の生じている半身を患側、そうで ない半身を健側という) の手でハンドリムを回して駆動 し、足で方向付けを行っているのが現状である。その他 に電動車いすを利用することも考えられるが、介護の基 本に「残存能力を活かし，機能を回復する」という考え方 があり、自立支援ということを考えると電動車いすを使 うことは、使用者の残存能力を最大限に利用するには有 効ではない。

そこで、片手片足のみで操作できる操作補助ユニット を提案する。操作アシスト方法は、健側側車輪に対して 患側側車輪を駆動するモー夕を制御し、両方の車輪を同 方向に同回転数で駆動することで直進動作を行い、逆方 向に同回転数で駆動することで、その場での旋回動作を 可能する。

制御目的は、健側側車輪の回転角を目標値として患側 側車輪を追従するように駆動することである。その方法 として、内部モデル制御(IMC) と最適レギュレータの極 限的性質 ${ }^{1)}$ を併用した方式を利用する。この制御方式は、 良好な目標追従性が得られることが知られており、実際 のメカニカルシステムの制御においもその有効性が確認 されている。2),3)

本研究では、この制御方式を車いすの制御に応用し、 実用化を考慮したマイコン化を行うための簡易模型を試 作してその有効性を検証すると共に、車輪の抵抗値の変 化や急発進、停止時の環境の変化に応じ種々な試験を可 能にすることを狙いとしている。なお、現在の段階で実. 際の車いすをパーソナルコンピュータとモー夕駆動電源 用安定化電源を用いて、車いすの制御に成功している。 4)本研究は、マイコン化による完全独立型の片手片足で 操作できる車いすの実用化を目指すための基礎研究であ る。

2. 標準型車いす用の操作補助ユニット
・標準型車いすに取り付けられる構造とすること。

・折りたたみの機能を損なわないこと。

・直進性能、旋回性能がよいこと。

・操作が簡単であること。

・残存能力を活用し片手片足だけで操作できること。

・軽量、低コストであること。

操作補助ユニットを標準型車いすに取り付けた様子を Fig.1(a)に、直進・旋回を決定するスイッチをフットレス 卜に取り付けた様子を Fig.1(b)示す。今回は、標準型車 いすの左側に操作補助ユニットを取り付けた。一方、マ イコン制御を行う装置は、駆動部、操作部および制御部 から成る。(Fig.2) 駆動部は追従輪を駆動するモー夕、ギ ヤボックス、モータおよびバッテリなどから構成され、 操作部は直進・旋回の動作を選定するスイッチ、制御部 は各々の車輪の回転角度を計測するロータリエンコーダ、 制御則の演算を行うマイコン、モータを駆動するための ドライバから構成される。

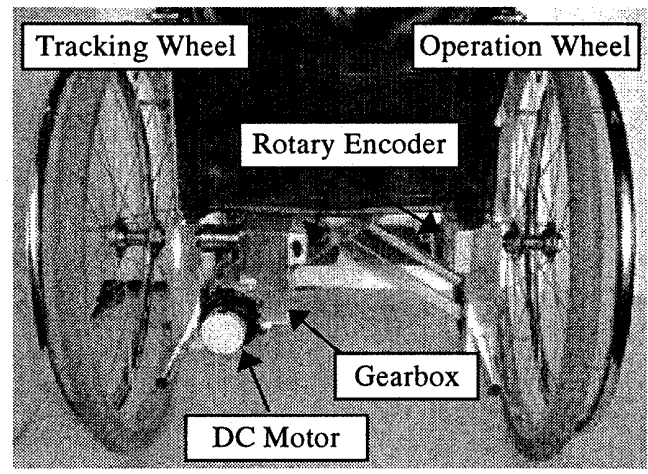

Fig. 1(a) Assisting unit for standard wheelchair

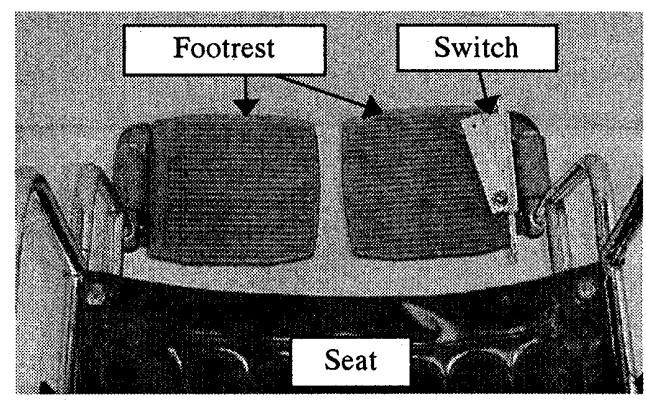

Fig. 1(b) Switch on footrest

操作補助ユニットは、次の要求を満足するものとする。 


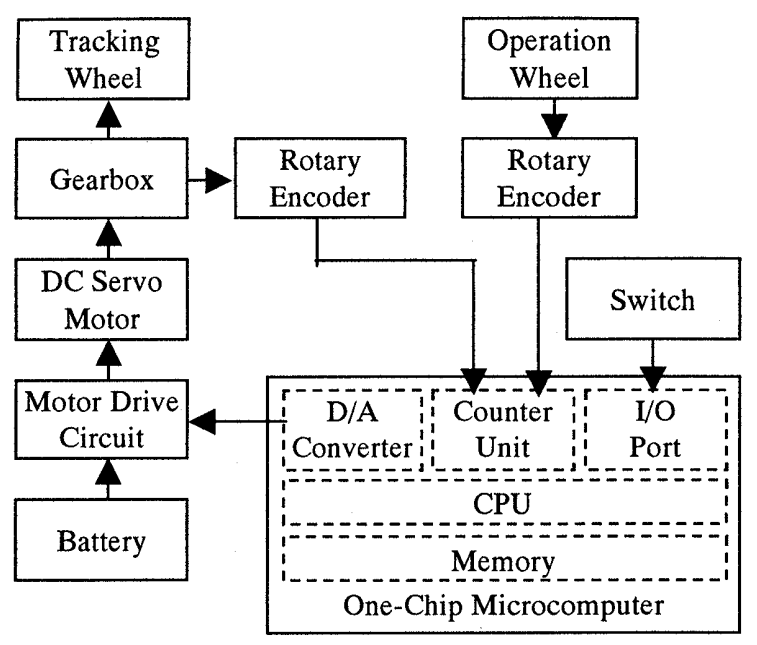

Fig. 2 Control system structure

3. 制御システムの設計と応用

3.1 IMC 制御と $L Q$ 制御の併用

次の線形システムについて考える。

$\dot{x}=A x+B u, \quad y=C x$

ただし、 $x \in R^{n}, y \in R^{P}, u \in R^{m}$ であり、システムは 可制御、可検出とする。このシステムに対して次の評価 関数を考える。

$$
J=\int_{0}^{\infty}\left(y^{T} Q y+u^{T} R u\right) d t, \quad Q>0, R>0
$$

ここで、 $Q 、 R$ は重み行列で $Q$ は半正定な対称行列、 $R$ は正定な対称行列とする。この評価関数 $J$ が最も小さく なる制御入力 $u$ を求める問題が最適制御問題であり、そ の解は、

$$
u=F x=-R^{-1} B^{T} P x
$$

というフィードバック則で与えられ、 $P$ はリカッチ方程 式

$$
A^{T} P+P A-P B R^{-1} B^{T} P+C^{T} Q C=0
$$

を満たす一意正定解である。特に、 $R=I, Q \rightarrow I / \rho^{2}(\rho \rightarrow 0)$ としたときに得られるフィードバックゲイン $F_{\infty}=-B^{T} P_{\infty}$ とすると、次の補題 1 に示すような外乱除去 特性が知られている。なお、 $P_{\infty}$ は(4)式の解である。

\section{[補題 1] $]^{1)}$}

外乱 $\xi \in R^{r}$ が印加されるシステムについて考える。

$$
\dot{x}=A x+B u+D \xi, \quad y=C x
$$

LQ 制御の極限フィードバックゲイン $F_{\infty}$ を施した、この 閉ループ系は次式を保つことで外乱分離が達成できる。

$$
\lim _{\rho \rightarrow 0} C\left(s I-A-B F_{\infty}\right)^{-1} D=0
$$

一方、外乱の影響を除去する手法に外乱分離制御があ る。これは、(1)式のシステムが条件

$$
v^{*}+\operatorname{Im} B \supset \operatorname{Im} D
$$

$v^{*}$ は、 $\operatorname{Ker} C$ に含まれる最大 $A-B$ 不変部分空間 のもとで、制御則

$$
u=F x+G \xi
$$

によって

$$
C(s I-A-B F)^{-1}(B G+D)=0
$$

とする制御である。しかし、一般に外乱の情報を入手す ることは困難である。そこで、本研究では(8)式のフィー

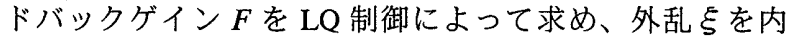
部モデル制御で推定し外乱を除去することを考える。

さて、ここで扱う車いすのようなメカニカルシステム は、入力端から外乱が印加されることが多いため(5)式を 次のように表す。

$$
\dot{x}=A x+B(u+\xi), \quad y=C x
$$

このシステムに対して Fig.3 のような構成を考える。 ただし、 $\sum f$ は制御対象に状態フィードバックを施した 伝達関数であり、 $\bar{\Sigma}_{f}$ は $\sum_{f}$ のモデル、 $\bar{\Sigma}_{f \varepsilon}^{-1}$ は $\bar{\Sigma}_{f}$ の近似 逆システムで次のように定義される。

$$
\bar{\Sigma}_{f \varepsilon}^{-1} \bar{\Sigma}_{f}=\operatorname{diag}\left((\varepsilon s+1)^{-d_{1}}, \cdots,(\varepsilon s+1)^{-d m}\right)
$$

ただし、 $\varepsilon$ は実現の可能性と目標追従、外乱推定の精度 を考慮して比較的小さい值として選定されるパラメータ であり、di は $\bar{\Sigma}_{f \varepsilon}^{-1}$ をプロパーとする次数で最小積分指数 と呼ばれる。

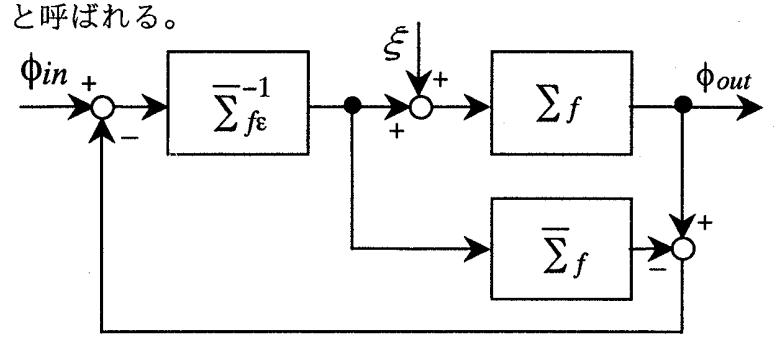

Fig. 3 IMC structure with LQ control

$[\text { 性質 1 }]^{3)}$

フィードバック $u=F_{\infty} x$ による(5)式のシステムの閉ル 一プ系を内部モデル制御の構成にすることで、内部モデ ル制御の構造がもつ外乱除去特性と最適レギュレータの 極限的性質がもつ外乱除去特性の相乗効果により $\rho, \varepsilon$ $\rightarrow 0$ の極限において、外乱の影響が減少し目標追従性が 高まることになる。

\section{2 モデリングと制御系設計}

車いすの片車輪のモデルを Fig.4 に示し、同図の車輪 軸であるO点周りのトルクのつりあいを考えた運動方程 式を(12)に示す。

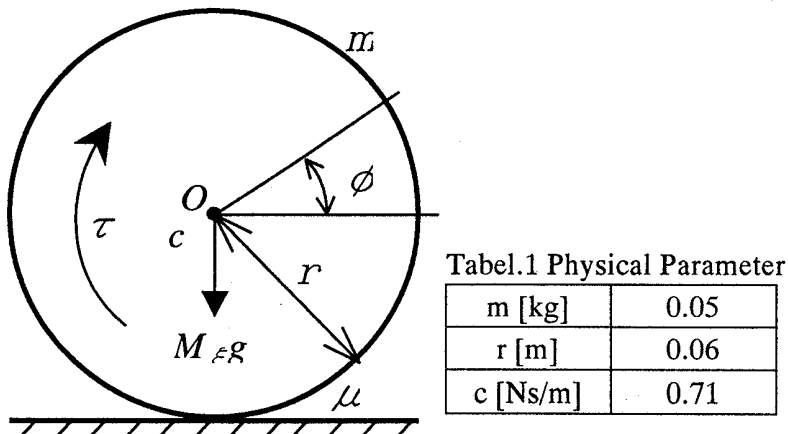

Fig. 4 Dynamics of wheel model 


$$
m r^{2} \ddot{\phi}+c r^{2} \dot{\phi}+\mu M \xi g r=\tau
$$

$m$ は車輪の質量、 $r$ は夕イヤの半径、 $\tau$ は夕イヤに加わ るトルク、 $\phi$ は夕イヤの回転角度、 $c$ は夕イヤまわりの 粘性抵抗、 $\mu$ は車輪と地面の摩擦抵抗である。 $M_{\xi}$ は設計 時の基本重量と異なる場合の質量誤差である。モデルの 各パラメータを Table.1に示す。

状態変数を $x=\left[\begin{array}{ll}\phi & \dot{\phi}\end{array}\right]^{T}$ 、操作入力を $u=\tau$ および外乱を $\xi=-\mu M \xi g r$ として制御対象の数式モデルを状態変数表 現したものを次に示す。

$$
\left\{\begin{array}{l}
\dot{x}=\left[\begin{array}{cc}
0 & 1 \\
0 & -\frac{c}{m}
\end{array}\right] x+\left[\begin{array}{c}
0 \\
1 \\
\hline m r^{2}
\end{array}\right] u+\left[\begin{array}{c}
0 \\
1 \\
\hline m r^{2}
\end{array}\right] \xi \\
y=\left[\begin{array}{ll}
1 & 0
\end{array}\right] x
\end{array}\right.
$$

次に最適レギュレータを利用して、このシステムに

$$
u=F_{\infty} x+v=\left[\begin{array}{ll}
f_{11} & f_{12}
\end{array}\right] x+v
$$

となる状態フィードバックを施すとシステムは次のよう に示すことができる。

$$
\left\{\begin{array}{l}
\dot{x}=\left[\begin{array}{cc}
0 & 1 \\
\frac{f_{11}}{m r^{2}} & -\frac{c}{m}+\frac{f_{12}}{m r^{2}}
\end{array}\right] x+\left[\begin{array}{c}
0 \\
\frac{1}{m r^{2}}
\end{array}\right] v+\left[\begin{array}{c}
0 \\
\frac{1}{m r^{2}}
\end{array}\right] \xi \\
y=\left[\begin{array}{ll}
1 & 0
\end{array}\right]
\end{array}\right.
$$

近似逆システムは次のように構成できる。

$$
\left\{\begin{array}{l}
\dot{z}=\hat{A} z+\hat{B} q \\
v=\hat{C} z+\hat{D} q
\end{array}\right.
$$

ここで、

$$
\begin{aligned}
& \hat{A}=\left[\begin{array}{cc}
0 & 1 \\
-\frac{1}{\varepsilon^{2}} & -\frac{2}{\varepsilon}
\end{array}\right], \quad \hat{B}=\left[\begin{array}{l}
0 \\
1
\end{array}\right], \quad \hat{D}=\frac{m r^{2}}{\varepsilon^{2}} \\
& \hat{C}=\left[-\frac{m r^{2}}{\varepsilon^{4}}-\frac{f_{11}}{\varepsilon^{2}}-\frac{2 m r^{2}}{\varepsilon^{3}}+\frac{c r^{2}-f_{12}}{\varepsilon^{2}}\right]
\end{aligned}
$$

である。以上により制御系の構成が完了する。

設計パラメータについては、シミュレーションおよび 実験による試行により、 $Q=800 I, R=I$ の場合のフィー ドバックゲイン $F_{800}=[-28.2843,-0.3166]$ とした。また、近 似逆システムのパラメータ $\varepsilon=0.08$ とした。

\section{4. 実験結果と性能評価}

\section{1 マイコン化のための簡易実験装置}

片麻疩者用車いすの操作ユニットをマイコン化するに は、机上で簡単に実験できる模型があれは、マイコン・ システムの構築と性能評価を行う際に便利であると考え た。この簡易模型の機能と目的を次に示す。

(1) 夕イヤ周りの粘性抵抗の変動、搭乗者の体重変化等 が等価的に再現できること。

(2) 設計パラメータの違いによる追従性の評価を行う ために、健側側ホイールを一様に回転させることが できること。

(3) 加速状態、減速状態および動き出し等の過渡状態の 実験ができこと。

これらの仕様を满足するために、患側側ホイールに プロニ・ブレーキを取り付け、負荷を調整することで 機能(1)を実現し、健側側ホイールをステッピングモー
タで駆動することで、(2)、(3)に関する評価を可能とし ている。模型の構成図を Fig.5 に、実際の模型を Fig.6 に示す。

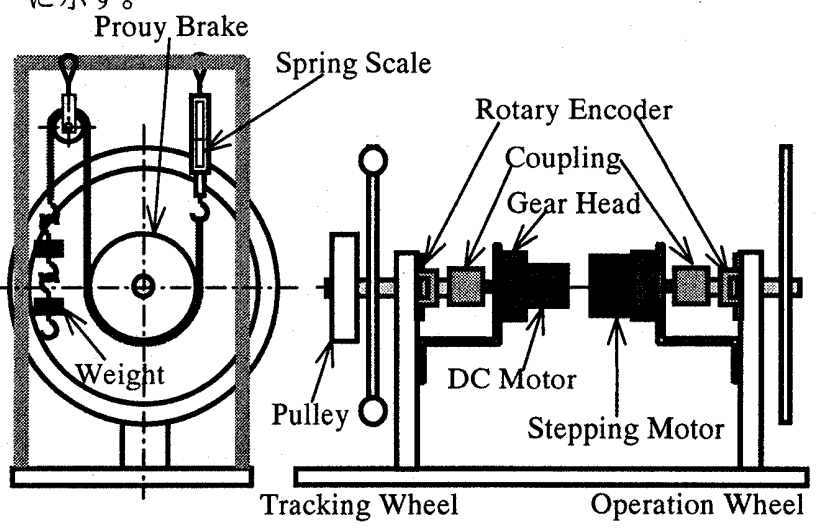

Fig. 5 Structure of trail system

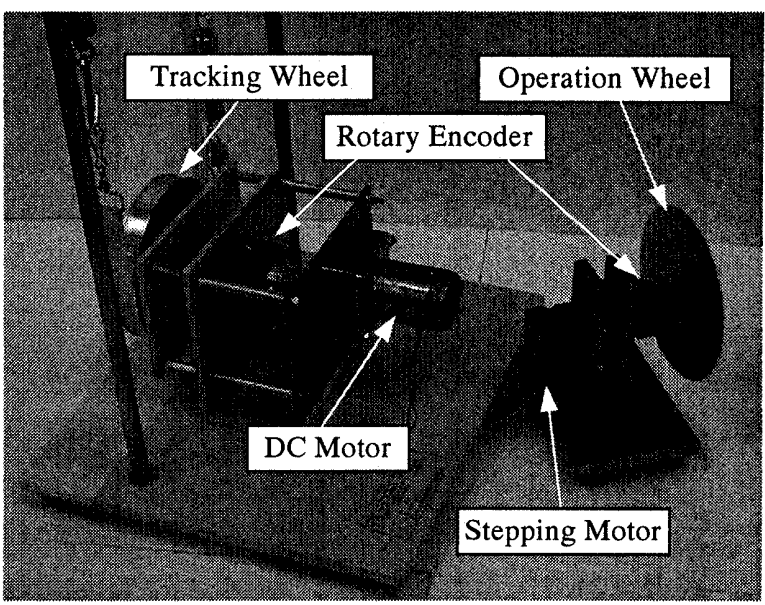

Fig. 6 Traial system

簡易模型の制御を行うマイクロコンピュータの構成を Fig.7 に示す。今回は、2台のマイコンを使い、患側側を メインマイコン、健側側をサブマイコンし、各々のエン コーダ信号をそれぞれのマイコンで計測している。メイ ンとサブマイコンは、それそれデータの受け渡しを同期 して行い、そのデータからメインマイコンが制御則に従 つて演算し DC モータを駆動する。

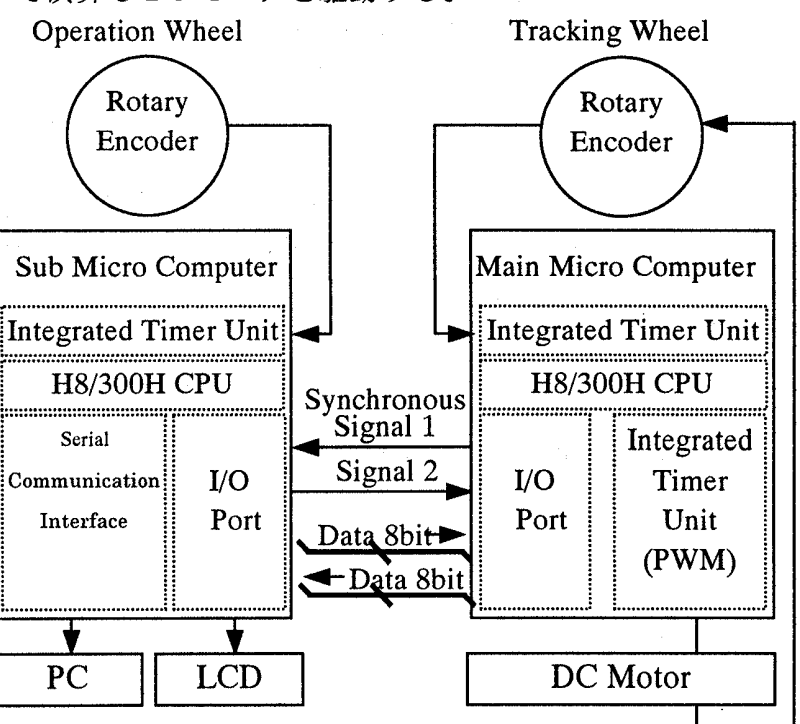

Fig. 7 Composition of microcomputer 


\section{2 実験方法と実験結果}

次の 2 種類の実験から追従性能の評価を行った。

(1) 実験 1

実験 1 の目的と方法は、搭乗者の体重の違いによる追 従性能を評価するために、プロニ・ブレーキの荷重を $0.05 \mathrm{~kg}$ と $1.0 \mathrm{~kg}$ の 2 種類とし健側側ホイールと患側側ホ イールの移動量を比較する。なお、このとき健側側の駆 動は、人の操作方法に近い正弦波状の駆動を与えた。

実験 1 の結果を Fig.8 と Fig.9 に示す。Fig.8 は、プロ ニ・ブレーキに $0.05 \mathrm{~kg}$ の負荷を与えたもので、Fig.9 は $1.0 \mathrm{~kg}$ の負荷を与えたものである。この実験結果から共 に良好な追従性能が認められ、負荷の変化があっても追 従性能の劣化は見られない。このことから、実際の車い すに応用した場合でも、搭乗者の体重変化や路面の変化 があっても良好に追従するものと考えられる。

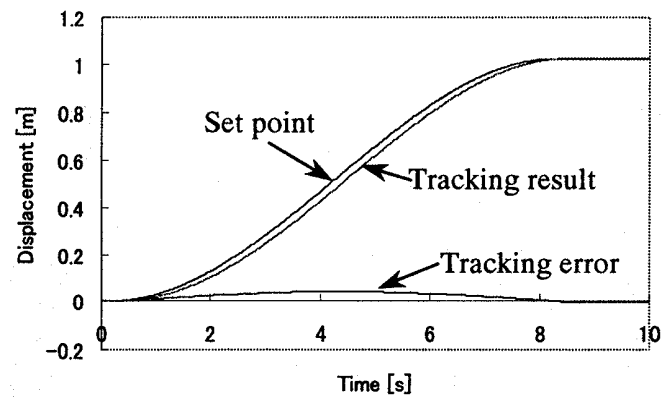

Fig. 8 Tracking result for forward movement; $0.05 \mathrm{~kg}$ load

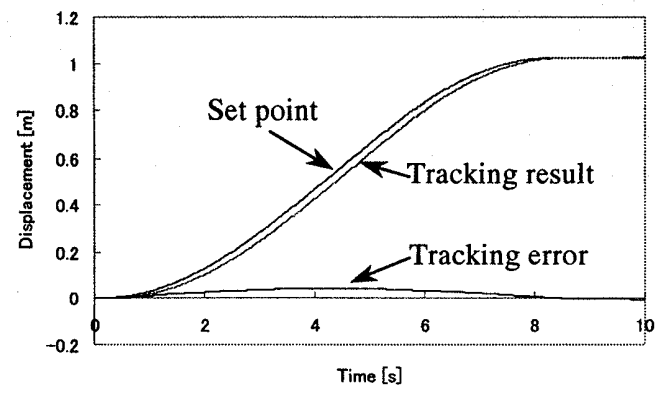

Fig. 9 Tracking result for forward movement; $1.0 \mathrm{~kg}$ load (2) 実験 2

実験 2 の目的と方法は、動き出しの瞬間や前進から後 進の切換えたとき等の過渡状態の追従性能を評価するた めに、健側側ホイールにステップ状の駆動を与え、しば らく後に前進から後進に回転方向を急に反転する方法で 行った。

実験 2 の結果を Fig.10 と Fig.11 に示す。始動時およ び前進から後進の切換えたときにも車いすの操作性に影 響を及ぼすと思われる遅れや振動も無く、良好な追従性 能が確認できた。

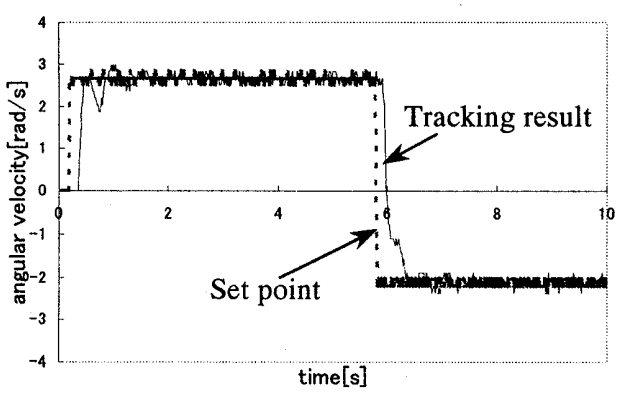

Fig. 10 Sudden movement (forward / backward)

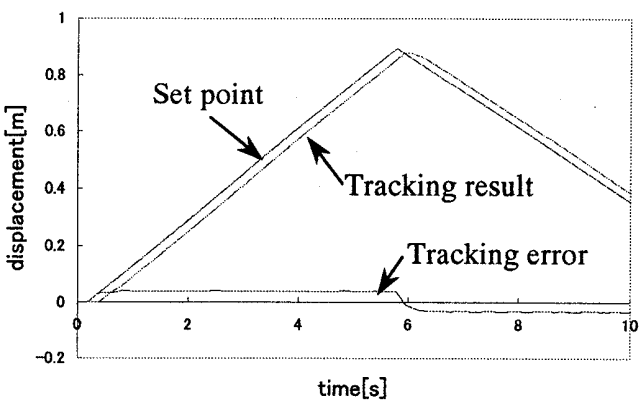

Fig. 11 Sudden movement (forward / backward)

5. おわりに

本研究では、標準車いすに内部モデル制御と最適制御 を利用した操作補助ユニットを取り付け、片手片足のみ で直進・旋回を可能とする「片手で標準型車いすを操作 するための走行補助装置」の製作と、各種パラメー夕の 変動と操作方法における制御装置の評価を行うための 「実用化を考慮したマイコン制御式の簡易模型」の製作 を行った。

この簡易模型を用いて、搭乗者の体重変化や路面状態 の変化等の環境変化と、急発進、急停止および前進から 後進の切換え時等の過渡時における追従性についての実 験を行った。内部モデル制御と最適レギュレータの極限 的性質を併用した制御系設計法で構築したマイコン化の 簡易模型では、どの場合も良好な追従結果であり有効性 が確認できた。

この研究で得られた成果は次の通りである。

・内部モデル制御と最適レギュレータの極限的性質を 併用した制御系設計法を応用し、片手で車いすを操 作するためのマイコン化方法を提案した。

・実験により提案手法が有効であることを確認した。

- 体重の変化や路面状況の変化のようなパラメー夕変 動に対して、有効に作動することを実験により示し た。

最後に今後の重要課題は、信頼性や安全性を向上する ための性能を高めることと、制御装置のマイコン化、駆 動回路の小型化、バッテリ電源による車いすの独立化で ある。また、駆動力のオン/オフ機能を付加することも車 いす利用者の利便性を図るために必要と考える。

\section{参考文献}

1) 小林、櫻井、中溝、矢野、最適レギュレー夕の極限 形式と外乱分離問題、計測自動制御学会論文集、 Vol.34, No.6, 563/570(1998)

2) 板本、小林、神崎、中溝、内部モデル制御と最適レ ギュレータの極限的性質を併用した外乱除去制御、 精密工学会誌、Vol.62, No.9, 1287/1291 (1996)

3) 鈴木、小林、土肥、古屋、倉川、内部モデル制御と 最適レギュレータの極限的性質の相乗効果を利用し た軌道追従制御、日本機械学会論文集(C 編)、Vol.67, No.663, 3519/3524 (2001)

4) R.Suzuki, M.Tani and N.Kobayashi, "Design and development of single side driven wheelchair by using internal model control", In proc. IEEE Conference on Control Applications, Glasgow. 2002 